\title{
DAMPAK IMPLEMENTASI MODEL PEMBELAJARAN PROJECT- WORK BERBASIS KARAKTER TERHADAP SIKAP DAN PRESTASI BELAJAR MAHASISWA
}

\author{
Alifia Zahra Khoirunisa ${ }^{1}$, I. Ketut Sunarya ${ }^{2}$, Dwi Rahdiyanta ${ }^{3}$ \\ ${ }^{1}$ Program Pascasarjana Universitas Negeri Yogyakarta, Indonesia; ${ }^{2}$ Jurusan Pendidikan Kerajinan, Universitas Negeri \\ Yogyakarta, Indonesia ${ }^{3}$ Jurusan Pendidikan Teknik Mesin, Universitas Negeri Yogyakarta, Indonesia \\ Email: Alifiazahra.2018@student.uny.ac.id
}

\begin{abstract}
The purpose of this study was to determine the effect of the implementation of character-based projectwork learning model in practical subjects to student attitudes and learning achievement. This research was conducted using the Research and Development approach with a quasi experiments design. The population of this research is 33 students of Complex Machining Process course in Mechanical Engineering Diploma Study Program of Universitas Negeri Yogyakarta. Research data were collected using observation sheets, documentation, evaluation of learning outcomes and interviews. To determine the effect of the model, $t$-test analysis techniques were employed. Results of the research are: 1) there are attitude or behavior differences of the students between the character-based project-work learning model class and the regular class $(t=7.31 ; p=$ $0,000)$; and 2) there are achievement differences of the students between the model classes and the regular class $(t=9.47 ; p=0,000)$.
\end{abstract}

Keywords: character-based, project-work learning, practical learning, vocational education

\begin{abstract}
ABSTRAK
Tujuan penelitian ini adalah untuk mengetahui pengaruh dari penerapan model pembelajaran projectwork berbasis karakter pada mata kuliah praktik terhadap sikap dan prestasi belajar mahasiswa. Penelitian ini dilaksanakan dengan pendekatan Research and Development. Desain eksperimen menggunakan quasi eksperimen. Populasi penelitian ini adalah mahasiswa mata kuliah proses pemesinan kompleks pada Diploma III Program Studi Teknik Mesin Fakultas Teknik Universitas Negeri Yogyakarta yang berjumlah 33 mahasiswa. Data penelitian dikumpulkan menggunakan lembar observasi, dokumentasi, evaluasi hasil belajar dan wawancara. Untuk mengetahui pengaruh dari penggunaan model pembelajaran project-work berbasis karakter digunakan teknik analisis uji-t. Hasil penelitian yang telah dilaksanakan adalah: 1) ada perbedaan sikap atau perilaku mahasiswa antara kelas yang diajar dengan model pembelajaran project-work berbasis karakter dibandingkan dengan kelas biasa ( $\mathrm{t}=7,31 ; \mathrm{p}=0,000)$; dan 2) ada perbedaan prestasi belajar mahasiswa antara kelas yang diajar dengan model pembelajaran project-work berbasis karakter dibandingkan dengan kelas biasa $(t=9,47 ; p=0,000)$.
\end{abstract}

Kata kunci: pembelajaran project-work berbasis karakter, pembelajaran praktik, pendidikan vokasional

\section{PENDAHULUAN}

Pada dasarnya setiap produk barang yang dihasilkan oleh suatu industri manufaktur tersusun dari beberapa bagian atau komponenkomponen yang dirangkai atau dipadukan menjadi suatu unit atau produk tertentu. Untuk menghasilkan produk yang berkualitas tinggi sudah barang tentu diperlukan berbagai kompetensi baik yang terkait dengan kompetensi akademik (hard-skill), maupun kompetensi yang terkait dengan nilai karakter (soft-skill), yang antara lain memiliki sikap teliti, telaten, disiplin, peduli, mandiri, percaya diri, kemampuan kerjasama dan jujur. Dalam proses pembuatan suatu produk yang berkualitas yang tersusun dari banyak komponen tentu diperlukan suatu proses kerja yang baik dan sistematis. Salah satu sistem kerja yang biasa digunakan sering disebut 
dengan istilah project-work.

Pendidikan vokasional memiliki tujuan untuk menghasilkan lulusan yang siap pakai atau siap kerja. Untuk membentuk lulusan yang siap kerja tersebut di samping dituntut untuk menguasai kompetensi di bidang akademik (hard-skill), juga perlu ditanamkan akhlak mulia atau nilai karakter (soft-skill) kepada peserta didiknya. Untuk itu agar pembelajaran praktik yang diselenggarakan dapat berjalan dengan efektif, baik dalam memberikan kompetensi akademis maupun dalam menanamkan nilai karakter, maka diperlukan inovasi pengajar dalam menerapkan dan mengembangkan metode atau model pembelajarannya sehingga tujuan pembelajaran dapat tercapai secara maksimal yaitu dikuasainya kompetensi akademis dan dimilikinya karakter yang baik oleh peserta didik.

Menurut Calhoun and Finch (1976: 2), bahwa pengertian pendidikan vokasional dikembangkan dari terjemahan konsep vocational education (pendidikan vokasional) dan occupational education (pendidikan keduniakerjaan), yang berarti suatu program pendidikan yang secara langsung dihubungkan dengan persiapan seseorang untuk memasuki dunia kerja, atau untuk persiapan tambahan yang diperlukan dalam suatu karir. Lebih lanjut menurut Finch dan Crunkilton (1979: 2) pendidikan vokasional diartikan sebagai pendidikan yang memberikan bekal kepada peserta didik agar dapat bekerja guna menopang kehidupannya. Berdasarkan pendapat tersebut berarti bahwa pendidikan vokasional diperlukan untuk menyiapkan peserta didik agar siap kerja baik di dalam lingkungan maupun di luar lingkungan masyarakat. Oleh karena itu para pendidik dan pembuat kebijakan dibidang pendidikan vokasional perlu menyiapkan pondasi yang kuat dalam proses belajar mengajar bagi para peserta didik untuk penguasaan keterampilan akademis maupun konsep-konsep yang diperlukan untuk menghadapi dunia kerja yang sesungguhnya.

Menurut Wardiman (1998), karakteristik pendidikan vokasional memiliki ciri: 1) diarahkan untuk mempersiapkan peserta didik memasuki lapangan kerja, 2) didasarkan atas “demand-driven” (kebutuhan dunia kerja), 3) ditekankan pada penguasaan pengetahuan, keterampilan, sikap dan nilai-nilai yang dibutuhkan oleh dunia kerja, 4) penilaian terhadap kesuksesan peserta didik harus pada "hands-on" atau performa dunia kerja, 5) hubungan yang erat dengan dunia kerja merupakan kunci sukses pendidikan vokasi, 6) bersifat responsive dan antisipatif terhadap kemajuan teknologi, 7) lebih ditekankan pada "learning by doing" dan hands-on experience, dan 8) memerlukan fasilitas yang memadai untuk pembelajaran praktik.

Berdasarkan berbagai pendapat di atas, jelas bahwa titik berat pendidikan vokasi adalah membekali peserta didik dengan seperangkat keterampilan dan kemampuan yang dapat digunakan untuk bekerja atau mengembangkan diri sesuai bidang keahliannya. Dengan demikian, penyusunan standar kompetesi yang sesuai dengan tuntutan dunia kerja atau industri sangat dibutuhkan dalam rangka untuk meningkatkan mutu pendidikan tinggi vokasional.

Pembelajaran berbasis proyek adalah pembelajaran yang dilakukan perseorangan maupun kelompok dan dilaksanakan dalam jangka waktu tertentu untuk menghasilkan sebuah produk yang kemudian ditampilkan atau dipresentasikan. Menurut Fortus (2015), pembelajaran project-work merupakan proses pembelajaran yang memberikan penekanan kuat pada pemecahan masalah sebagai suatu kolaboratif. Menurut Alamaki (2014), bahwa proyek selain dilakukan secara kolaboratif juga harus bersifat inovatif, unik, dan fokus pada pemecahan masalah nyata yang berhubungan dengan kebutuhan masyarakat.

Pembelajaran berbasis proyek adalah suatu pendekatan pembelajaran yang inovatif, yang menekankan belajar kontekstual melalui kegiatan-kegiatan yang kompleks (Bern dan Ericson, 2010). Fokus pembelajaran terletak 
pada penanaman konsep dan prinsip inti dari suatu disiplin studi, melibatkan peserta didik dalam investigasi pemecahan masalah dan memberi kesempatan peserta didik bekerja secara otonom mengkonstruk pengetahuan mereka sendiri, untuk menghasilkan produk nyata (Arends, 2010). Dengan demikian pembelajaran berbasis proyek ini memiliki potensi yang amat besar untuk membuat pengalaman belajar yang lebih menarik dan bermakna.

Tidak semua kegiatan belajar aktif dan melibatkan proyek dapat disebut sebagai pembelajaran berbasis proyek. Terdapat lima kriteria suatu pembelajaran dapat disebut sebagai pembelajaran berbasis proyek, yaitu: 1) keterpusatan (centrality), 2) fokus pada pertanyaan atau masalah, 3) investigasi konstruktif atau desain, 4) otonomi peserta didik, dan 5) realisme. Adapun keuntungan dari metode pembelajaran berbasis proyek adalah: 1) meningkatkan motivasi peserta didik, 2) meningkatkan kemampuan memecahkan masalah, 3) meningkatkan kolaborasi, dan 4) meningkatkan keterampilan dalam mengelola sumber.

Pendidikan karakter ditempatkan sebagai landasan untuk mewujudkan visi pembangunan nasional, yaitu mewujudkan masyarakat berakhlak mulia, bermoral, beretika, berbudaya, dan beradab berdasarkan falsafah Pancasila (Sumber: Buku Induk Kebijakan Nasional Pembangunan Karakter Bangsa 2010-2025). Pendidikan karakter memegang peran yang sangat penting untuk mengatasi permasalahanpermasalahan kebangsaan yang berkembang saat ini, seperti bergesernya nilai etika dalam kehidupan berbangsa dan bernegara, memudarnya kesadaran terhadap nilai-nilai budaya bangsa, ancaman disintegrasi bangsa, dan melemahnya kemandirian bangsa.

Pendidikan karakter bukan hanya sekedar mengajarkan mana yang benar dan mana yang salah. Lebih dari itu, pendidikan karakter adalah usaha menanamkan kebiasaan-kebiasaan yang baik (habituation) sehingga peserta didik mampu bersikap dan bertindak berdasarkan nilai-nilai yang telah menjadi kepribadiannya. Dengan kata lain, pendidikan karakter yang baik harus melibatkan pengetahuan yang baik (moral knowing), perasaan yang baik atau loving good (moral feeling) dan perilaku yang baik (moral action) sehingga terbentuk perwujudan kesatuan perilaku dan sikap hidup peserta didik (Sumber: Buku Induk Pembangunan Karakter, 2010).

Dalam rangka lebih memperkuat pelaksanaan pendidikan karakter pada satuan pendidikan telah teridentifikasi 18 nilai yang bersumber dari agama, Pancasila, budaya, dan tujuan pendidikan nasional, yaitu: (1) Religius, (2) Jujur, (3) Toleransi, (4) Disiplin, (5) Kerja keras, (6) Kreatif, (7) Mandiri, (8) Demokratis, (9) Rasa Ingin Tahu, (10) Semangat Kebangsaan, (11) Cinta Tanah Air, (12) Menghargai Prestasi, (13) Bersahabat/ Komunikatif, (14) Cinta Damai, (15) Gemar Membaca, (16) Peduli Lingkungan, (17) Peduli Sosial, (18) Tanggung Jawab (Sumber: Pusat Kurikulum. Pengembangan dan Pendidikan Budaya dan Karakter Bangsa: Pedoman Sekolah. 2009:9-10). Meskipun telah dirumuskan 18 nilai pembentuk karakter bangsa, namun satuan pendidikan dapat menentukan prioritas pengembangannya untuk melanjutkan nilai-nilai prakondisi yang telah dikembangkan. Implementasi nilai-nilai karakter yang akan dikembangkan dapat dimulai dari nilai-nilai yang esensial, sederhana, dan mudah dilaksanakan, seperti: bersih, rapi, nyaman, disiplin, jujur, sopan dan santun (Depdiknas, 2003).

Berdasarkan kenyataan tersebut, menjadi tanggung jawab dunia pendidikan khususnya pendidikan vokasional untuk menciptakan lulusan yang selain memiliki kompetensi akademik juga berkarakter unggul. Oleh karena itu menjadi keharusan untuk mengintegrasikan nilai-nilai karakter dalam proses pembelajaran, tak terkecuali dalam pembelajaran praktik. Salah satu upaya untuk mengintegrasikan nilainilai karakter dalam pembelajaran praktik adalah dengan mengembangkan model 
pembelajaran project-work berbasis karakter pada pembelajaran praktik di pendidikan tinggi vokasi. Adapun permasalahan yang akan dibahas dalam penelitian ini adalah: (1) apakah penerapan model pembelajaran project-work berbasis karakter pada mata kuliah praktik berpengaruh terhadap pembudayaan karakter atau sikap kerja pada mahasiswa dan (2) apakah penerapan model pembelajaran project-work berbasis karakter pada mata kuliah praktik berpengaruh terhadap peningkatan prestasi belajar praktik mahasiswa.

\section{METODE}

Penelitian ini dilakukan dengan menggunakan pendekatan Research and Development yang dikembangkan oleh Borg and Gall (1998:782), dan dilanjutkan dengan penelitian eksperimen untuk mengetahui keefektifan model yang dikembangkan. Tanpa mengurangi validitas proses dan temuan dalam penelitian ini, Research and Development yang dikembangkan Borg dan Gall, diadaptasi dan diadakan sedikit modifikasi dalam tahapannya. Adapun tahapan dalam penelitian ini adalah sebagai berikut: (1) studi pendahuluan untuk mengumpulkan informasi tentang kebutuhan pengembangan; (2) penyusunan model konseptual; (3) melakukan validasi dan revisi model konseptual melalui kegiatan FGD; (4) uji coba model konseptual, dan 5) implementasi dan diseminasi model.

Lokasi untuk kegiatan penelitian ini adalah industri manufaktur dan Jurusan Pendidikan Teknik Mesin FT UNY. Populasi penelitian adalah semua mahasiswa yang mengambil mata kuliah proses pemesinan kompleks yang berjumlah 85 mahasiswa. Sampel penelitian ditetapkan sebanyak 33 mahasiswa. Teknik penentuan jumlah sampel berdasarkan purposive sampling. Dari 33 mahasiswa tersebut terdiri dari dua kelas praktek yang masing-masing berjumlah 16 mahasiswa (kelas eksperimen) dan 17 mahasiswa (kelas kontrol). Teknik pengumpulan data pada penelitian ini menggunakan lembar observasi, angket, dokumentasi, evaluasi hasil belajar dan wawancara. Lembar observasi digunakan pada saat uji coba model. Angket dan wawancara digunakan untuk menggali data kompetensi dan aspek karakter yang dibutuhkan oleh pihak industri. Dokumentasi digunakan untuk mendokumentasikan beberapa kegiatan yang telah dilaksanakan. Data hasil penelitian dianalisis dengan cara kualitatif dan kuantitatif. Untuk menguji keefektifan model yang dikembangkan dibandingkan dengan model yang lama, dianalisis dengan menggunakan metode $t$-test.

\section{HASIL DAN PEMBAHASAN}

Pada tahapan studi pendahuluan diawali dengan mengkaji berbagai literatur dan hasil penelitian yang relevan, peraturan dan pedoman penyelenggaraan pembelajaran praktik berdasar kurikulum, identifikasi kompetensi yang akan dicapai, serta analisis kebutuhan terhadap pengembangan model. Kegiatan selanjutnya adalah observasi ke industri manufaktur untuk menggali informasi tentang kompetensi dan aspek karakter yang dibutuhkan di industri serta iklim atau sistem kerja di industri. Alat untuk menggali informasi tersebut menggunakan angket tertutup yang berisi daftar kompetensi akademik yang diturunkan dari Standar Kompetensi Kerja Nasional Indonesia (SKKNI), serta aspek karakter yang disesuaikan dengan karakter kerja praktik manufaktur. Hasil dari kegiatan ini dapat dilihat dalam Tabel 1 berikut ini.

Tabel 1. Persentase tingkat kebutuhan kompetensi

\begin{tabular}{clcccc}
\hline \multirow{2}{*}{ No } & $\begin{array}{l}\text { Jenis } \\
\text { Kompetensi }\end{array}$ & $\begin{array}{c}\text { TP } \\
(\%)\end{array}$ & $\begin{array}{c}\text { CP } \\
(\%)\end{array}$ & $\begin{array}{c}\text { P } \\
(\%)\end{array}$ & $\begin{array}{c}\text { SP } \\
(\%)\end{array}$ \\
\hline 1 & Akademik & 1.11 & 6.67 & 37.78 & 54.44 \\
2 & $\begin{array}{l}\text { Aspek } \\
\text { karakter }\end{array}$ & 0 & 6.67 & 35.56 & 57.78 \\
\hline & Rerata & 1.11 & 6.67 & 36.67 & 56.11 \\
\hline
\end{tabular}

Keterangan :

TP: Tidak Penting, CP: Cukup Penting, P: Penting, SP: Sangat Penting 
Hasil dari kegiatan studi pendahuluan menjadi acuan dalam menyusun draft model konseptual yang akan dikembangkan. Draft awal yang telah disusun dapat dilihat pada Gambar 1 berikut ini.

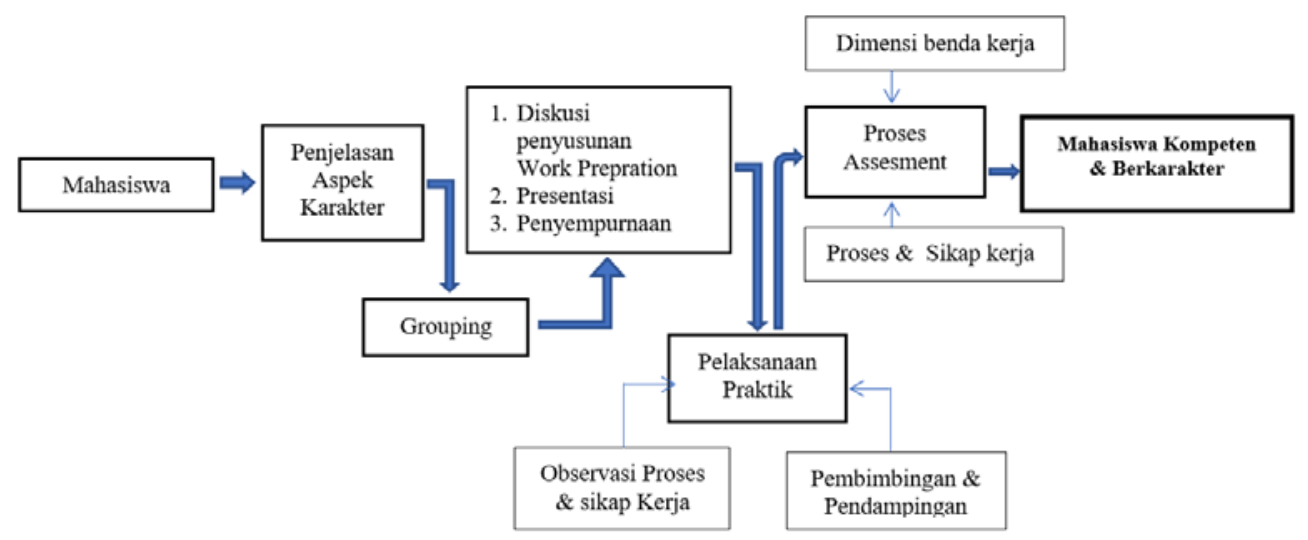

Gambar 1. Draft awal Model Konseptual

Proses validasi dilakukan melalui kegiatan FGD. Berdasarkan hasil kegiatan ini, terdapat beberapa saran dan masukan untuk merevisi draft konseptual yang telah dikembangkan. Berdasarkan saran dan masukan pada kegiatan ini, maka diadakan revisi terhadap draft model konseptual yang telah dikembangkan, yaitu pada proses penjelasan aspek karakter dan proses Assessment.

Berdasarkan masukan dan saran dari para pakar dan praktisi industri manufaktur, maka proses Penjelasan Aspek Karakter direvisi menjadi kegiatan Eksplorasi Aspek Karakter. Kegiatan eksplorasi ini dimaksudkan untuk menggali pengetahuan dan pemahaman mahasiswa terhadap aspek karakter yang dapat diintegrasikan ke dalam pembelajaran praktik pemesinan, sehingga diharapkan apabila mahasiswa mengetahui dan memahaminya dengan baik, maka aspek karakter akan membudaya dalam kegiatan pembelajaran praktik.

Proses assessment yang semula hanya dilakukan oleh dosen saja, berdasarkan masukan dan saran maka proses assessment selain dilakukan oleh dosen juga dilakukan secara self-assessment olah mahasiswa. Tujuan dari proses self-assessment adalah untuk membudayakan mahasiswa berlaku jujur serta memperdalam kemampuan mahasiswa dalam menggunakan alat ukur. Model konseptual yang telah direvisi dapat dilihat pada Gambar 2 berikut ini.

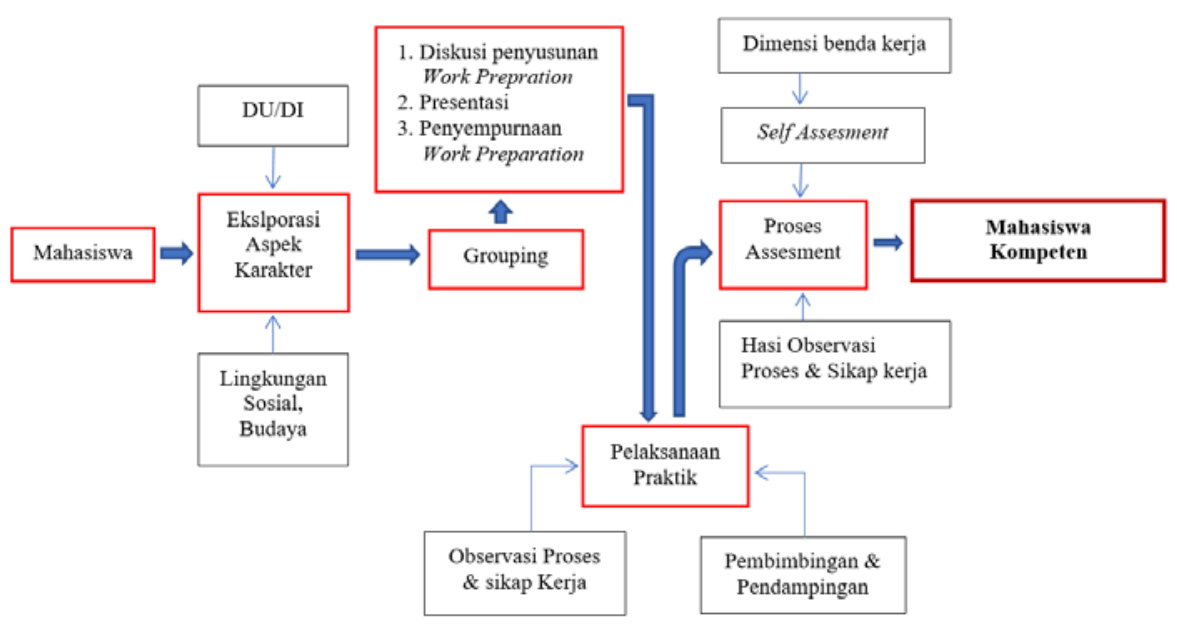

Gambar 2. Model Konseptual yang telah direvisi 
Tahapan pengembangan model yang telah direvisi tersebut dapat dijelaskan sebagai berikut:

Input (Mahasiswa). Input atau masukan adalah mahasiswa atau peserta didik yang akan mengikuti pembelajaran praktik pemesinan. Model pembelajaran ini dapat diterapkan dalam setiap pembelajaran praktik pemesinan tanpa membedakan tingkat atau semester berapa.

Eksplorasi nilai karakter. Eksplorasi nilai karakter disesuaikan dengan karakter kerja proses pemesinan yang ada di dunia kerja maupun di dunia industri, yaitu kemampuan membaca gambar kerja, memilih alat kerja dengan cerdas, menentukan langkah/prosedur kerja, menentukan kriteria kerja, menggunakan alat kerja dengan terampil, merawat alat kerja, menjaga sikap kerja, menjaga lingkungan kerja, mentaati keselamatan kerja, disiplin kerja, mampu bekerja dalam tim kerja, dan kepatuhan akan peraturan kerja. Disamping itu juga dilakukan eksplorasi aspek karakter yang ada masyarakat pada umumnya, yaitu sikap saling menghormati, jujur, toleran, empati, dan bisa bekerja sama.

Pada proses eksplorasi ini dilaksanakan dengan metode diskusi, dimana mahasiswa diminta untuk mengidentifikasi aspek atau nilai karakter apa saja yang harus dijalankan bilamana mereka melaksanakan praktik pemesinan. Hal ini dimaksudkan apabila mahasiswa sudah mampu menggali atau mengidentifikasi nilai karakter, maka tentunya mereka telah memiliki kesadaran untuk melaksanakan nilai-nilai karakter tersebut dalam proses pembelajaran praktik. Dengan demikian apabila mahasiswa melaksanakan praktik dengan prosedur yang benar, sehingga dengan sendirinya mahasiswa tersebut telah melaksanakan nilai karakter.

Pada tahapan ini, peran dosen adalah membantu mengarahkan dan menjelaskan setiap nilai karakter yang dapat diintegrasikan dalam pembelajaran praktik pemesinan.

Grouping. Pembentukan grup dilaksanakan oleh dosen dengan keanggotaan kelompok diambil secara acak. Grup dibentuk agar mahasiswa saling bekerjasama terutama dalam proses penyusunan Work Preparation (perencanaan kerja). Tujuan dari pembentukan grup ini adalah membiasakan mahasiswa untuk memiliki rasa toleran dan kerja sama. Setelah dibentuk kelompok, maka dosen dapat membagi job kerja masing-masing kelompok, untuk selanjutnya dipelajari terlebih dahulu oleh mahasiswa, kemudian disusun Work Preparation.

Penyusunan Work Preparation Sheet (lembar perencanaan kerja). Sebelum melaksanakan praktik, maka setiap mahasiswa diwajibkan menyusun Work Preparation Sheet (WPS) atau lembar perencanaan kerja dari setiap job praktik. Secara umum WPS berisikan urutan langkah kerja, alat dan mesin yang digunakan, perhitungan parameter pemotongan, prediksi waktu pekerjaan, alat dan tindakan keselamatan kerja. Dalam hal ini, WPS disusun secara berkelompok dengan harapan mahasiswa mampu bekerjasama dalam tim. WPS harus disusun secara runtut dan benar, sehingga mampu menjadi pedoman mahasiswa dalam melaksanakan praktik. Setelah WPS selesai disusun oleh setiap kelompok, kemudian dipresentasikan dalam kelas sehingga kelompok lain dapat memberikan masukan terhadap WPS yang dipresentasikan oleh kelompok lain tersebut. Dalam tahapan ini dosen berperan sebagai fasilitator dalam diskusi yang dilaksanakan dan bersama mahasiswa menyempurnakan WPS yang mereka susun. Dalam tahapan ini nilai karakter yang diintegrasikan adalah mampu bekerja sama dalam tim, berani mengungkapkan pendapat, dan toleransi.

Pelaksanaan Pembelajaran Praktik. Tahapan selanjutnya adalah masuk dalam pembelajaran praktik. Mahasiswa melaksanakan praktik dengan berpedoman pada langkah kerja atau prosedur kerja sesuai dengan WPS yang telah disusun. Sebagai salah satu alternatif job yang dapat dipraktikan adalah job yang bersifat collaborative skill, artinya sebuah job praktik yang terdiri dari beberapa komponen yang kemudian dipasangkan satu dengan 
lainnya. Sehingga job ini dapat dikerjakan secara berkelompok dimana masing-masing mahasiswa mendapatkan tugas untuk mengerjakan satu komponen. Dalam hal ini disamping mahasiswa harus bekerja sama, juga harus memiliki rasa untuk saling menyesuaikan atau toleransi sehingga komponen yang mereka kerjakan dapat dipasangkan dengan baik menjadi satu unit alat. Dalam pelaksanaan kegiatan praktik ini, dapat diamati proses kerja mahasiswa dan proses integrasi nilai karakter yang dilaksanakan oleh setiap mahasiswa dengan menggunakan lembar observasi. Peran dosen dalam kegiatan praktik adalah selalu memberikan pembimbingan dan pendampingan, sehingga mahasiswa segera mendapatkan solusi apabila mereka menemui kendala dalam melaksanakan praktik.

Proses Assessment. Tahapan terakhir adalah proses assessment, yang terdiri dari beberapa komponen penilaian, yaitu penilaian proses kerja, dimensi benda kerja dan hasil pengamatan aspek karakter mahasiswa. Untuk menanamkan rasa kejujuran pada mahasiswa, maka proses assessment dilakukan secara self assessment. Dengan self-assessment ini mahasiswa dipersilahkan memberikan skor hasil pengukuran terhadap dimensi benda kerja yang telah mereka kerjakan dengan menggunakan lembar assessment. Meskipun demikian dosen juga melakukan pengukuran terhadap dimensi benda kerja yang telah dikerjakan mahasiswa, sehingga dapat mengecek kebenaran dari pengukuran yang telah dilakukan oleh mahasiswa. Kemudian dosen memberikan penilaian atas hasil pembelajaran praktik mahasiswa.

d. Implementasi Model

Implementasi model pembelajaran dilaksanakan di Jurusan Pendidikan Teknik Mesin FT UNY, yaitu pada mata kuliah Proses Pemesinan Kompleks. Proses implementasi model dilaksanakan dengan menggunakan metode quasi eksperimen pada $\square$ ontrol $\square$ s yaitu kelas eksperimen (T1) dan kelas control (T2). Kelas T1 memiliki mahasiwa sebanyak 16 orang dan kelas T2 memiliki mahasiswa sebanyak 17 orang. Sedangkan untuk mengetahui pengaruh dari implementasi model ini digunakan uji-t.

Aspek karakter (soft-skill) yang diteliti pada implementasi model pembelajaran ini adalah disiplin, kerja keras, bekerja sama, jujur dan peduli. Sedangkan aspek prestasi belajar dalam penguasaan kompetensi di bidang proses pemesinan (hard-skill) adalah berupa praktik pembuatan speed-reducer, yang terdiri dari tiga komponen utama yaitu: poros roda gigi cacing, roda gigi cacing, dan poros ulir cacing.

Data hasil observasi terhadap proses pengintegrasian nilai-nilai karakter atau sikap mahasiswa dalam proses pembelajaran praktik pada kelas eksperimen dan kelas $\square$ ontrol dapat dilihat pada Tabel 2 berikut ini.

Tabel 2. Data observasi pengintegrasian nilai karakter

\begin{tabular}{|c|c|c|c|c|c|c|c|c|c|}
\hline \multirow[t]{2}{*}{ No } & \multirow[t]{2}{*}{$\begin{array}{c}\text { Aspek } \\
\text { karakter }\end{array}$} & \multicolumn{2}{|c|}{$\begin{array}{l}\text { Belum } \\
\text { terlaksana } \\
(\%) \\
\end{array}$} & \multicolumn{2}{|c|}{$\begin{array}{c}\text { Terlaksana belum } \\
\text { konsisten } \\
(\%) \\
\end{array}$} & \multicolumn{2}{|c|}{$\begin{array}{c}\text { Terlaksana secara } \\
\text { konsisten } \\
(\%) \\
\end{array}$} & \multicolumn{2}{|c|}{$\begin{array}{c}\text { Membudaya } \\
\text { (\%) }\end{array}$} \\
\hline & & $\mathrm{T} 1$ & $\mathrm{~T} 2$ & $\mathrm{~T} 1$ & $\mathrm{~T} 2$ & $\mathrm{~T} 1$ & $\mathrm{~T} 2$ & $\mathrm{~T} 1$ & $\mathrm{~T} 2$ \\
\hline 1 & Jujur & 5 & 10 & 5 & 20 & 10 & 20 & 80 & 50 \\
\hline 2 & Disiplin & 0 & 20 & 5 & 20 & 20 & 10 & 75 & 50 \\
\hline 3 & Kerja keras & 5 & 20 & 10 & 15 & 15 & 15 & 70 & 50 \\
\hline 4 & Kerja sama & 5 & 30 & 10 & 15 & 15 & 15 & 70 & 40 \\
\hline \multirow[t]{2}{*}{5} & Peduli & 0 & 20 & 0 & 20 & 25 & 20 & 75 & 40 \\
\hline & Rata-rata & 3 & 20 & 6 & 18 & 17 & 16 & 74 & 46 \\
\hline
\end{tabular}

Keterangan: T1= Kelas Eksperimen, T2= Kelas Kontrol 
Data hasil prestasi belajar proses pemesinan diambil dari penilaian benda kerja hasil praktik mahasiswa yang terdiri dari tiga macam job praktik, yaitu: 1) roda gigi cacing,
2) poros roda gigi cacing, dan 3) poros ulir cacing. Data hasil prestasi belajar mahasiswa pada kelas eksperimen dan kelas kontrol dapat dilihat pada Tabel 3 di bawah ini.

Tabel 3. Prestasi belajar mahasiswa

\begin{tabular}{|c|c|c|c|c|c|c|c|c|}
\hline \multirow{3}{*}{ Mhs. } & \multicolumn{6}{|c|}{ Job Praktik } & \multirow{2}{*}{\multicolumn{2}{|c|}{ Rata-rata }} \\
\hline & \multicolumn{2}{|c|}{ I } & \multicolumn{2}{|c|}{ II } & \multicolumn{2}{|c|}{ III } & & \\
\hline & $\mathrm{T} 1$ & $\mathrm{~T} 2$ & $\mathrm{~T} 1$ & $\mathrm{~T} 2$ & $\mathrm{~T} 1$ & $\mathrm{~T} 2$ & $\mathrm{~T} 1$ & $\mathrm{~T} 2$ \\
\hline 1 & 80 & 65 & 85 & 66 & 86 & 70 & 83.67 & 67.00 \\
\hline 2 & 78 & 60 & 85 & 65 & 87 & 65 & 83.33 & 63.33 \\
\hline 3 & 80 & 70 & 78 & 68 & 80 & 68 & 79.33 & 68.67 \\
\hline 4 & 75 & 72 & 85 & 70 & 87 & 70 & 82.33 & 70.67 \\
\hline 5 & 78 & 68 & 80 & 70 & 85 & 66 & 81.00 & 68.00 \\
\hline 6 & 80 & 72 & 80 & 60 & 85 & 60 & 81.67 & 64.00 \\
\hline 7 & 82 & 68 & 87 & 62 & 82 & 65 & 83.67 & 65.00 \\
\hline 8 & 80 & 70 & 80 & 65 & 84 & 62 & 81.33 & 65.67 \\
\hline 9 & 78 & 70 & 80 & 60 & 78 & 66 & 78.67 & 65.33 \\
\hline 10 & 80 & 65 & 80 & 65 & 82 & 72 & 80.67 & 67.33 \\
\hline 11 & 85 & 60 & 76 & 72 & 80 & 68 & 80.33 & 66.67 \\
\hline 12 & 75 & 70 & 86 & 66 & 80 & 60 & 80.33 & 65.33 \\
\hline 13 & 80 & 65 & 80 & 70 & 82 & 65 & 80.67 & 66.67 \\
\hline 14 & 80 & 60 & 82 & 65 & 85 & 65 & 82.33 & 63.33 \\
\hline 15 & 75 & 70 & 85 & 66 & 80 & 60 & 80.00 & 65.33 \\
\hline 16 & 82 & 72 & 80 & 60 & 85 & 60 & 82.33 & 64.00 \\
\hline 17 & & 72 & & 70 & & 70 & & 70.67 \\
\hline
\end{tabular}

Keterangan: T1= Kelas eksperimen, T2= Kelas kontrol

Job I: Roda gigi cacing; Job II: Poros roda gigi cacing; Job III: Ulir cacing

Sesuai dengan jenis analisis yang akan digunakan yaitu uji-t, maka uji persyaratan analisis yang dilakukan adalah uji normalitas dan homogenitas. Untuk menguji data berdistribusi normal atau tidak digunakan metode nilai rasio skewness dan rasio kurtosis. Data dapat dikatakan berdistribusi normal jika nilai rasio skewness dan nilai rasio kurtosis berada pada rentang -2 sampai dengan +2 (Muhammad Nisfiannoor, 2009). Dari hasil uji normalitas diperoleh kesimpulan bahwa distribusi data baik untuk kelas kontrol maupun eksperimen berdistribusi normal. Dalam hal ini untuk data kelas eksperimen, nilai rasio skewness variabel $(-1,748)$ dan rasio kurtosis (0,288), dan untuk kelas kontrol menunjukkan nilai rasio skewness variabel $(0,821)$ dan rasio kurtosis (-0,370). Homogenitas data hasil penelitian diuji dengan menggunakan levene statistic. Berdasarkan hasil pengujian dengan levene statistic diperoleh signifikansi 0,189 pada Based on Mean yang lebih besar 0,05. Dengan demikian data penelitian tersebut adalah homogen. Berdasarkan hasil uji persyaratan analisis tersebut, maka uji-t dapat dilakukan.

a. Sikap atau karakter Mahasiswa

Hasil penelitian mengenai sikap atau perilaku mahasiswa dalam proses pembelajaran praktik, menunjukkan bahwa 90\% dari mahasiswa kelas eksperimen, nilai sikap atau karakter telah terlaksana dengan konsisten dan membudaya pada diri mahasiswa, sedangkan untuk kelas kontrol hanya 64\% dari mahasiswa yang telah melaksanakan dengan konsisten dan membudaya. Berdasarkan hasil uji beda, diketahui nilai t-hitung $=7,31$ dengan $\mathrm{p}=0,000$. Dengan demikian terbukti bahwa terdapat perbedaaan dalam pengintegrasian nilai-nilai sikap atau karakter dalam proses pembelajaran praktik antara mahasiswa kelas eksperimen dengan kelas kontrol. Dalam hal ini 
pembudayaan karakter pada mahasiswa kelas eksperimen lebih baik jika dibandingkan dengan kelas kontrol.

\section{b. Prestasi Belajar Mahasiswa}

Dari hasil penelitian didapatkan nilai ratarata prestasi belajar kelas eksperimen adalah 81,35 sedangkan nilai rata-rata prestasi belajar kelas kontrol adalah 66,29. Berdasarkan hasil uji beda, diketahui nilai t-hitung $=9,47$ dengan $\mathrm{p}=0,000$. Dengan demikian terbukti bahwa terdapat perbedaaan yang signifikan antara prestasi belajar mahasiswa kelas eksperimen dengan kelas kontrol. Dalam hal ini prestasi belajar kelas eksperimen lebih baik jika dibandingkan dengan prestasi belajar mahasiswa pada kelas kontrol.

Pembahasan

Model pembelajaran project-work berbasis karakter, merupakan pengembangan dari model pembelajaran CBT dimana dalam proses pembelajarannya sekaligus mengintegrasikan aspek-aspek sikap atau perilaku. Model ini lebih dikhususkan untuk pembelajaran praktik, sehingga dalam pembelajaran ini lebih menonjolkan aspek kompetensi praktik atau keterampilan peserta didik. Aspek sikap/tingkah laku yang diintegrasikan tentunya dapat disesuaikan dengan karakter kerja mata kuliah praktik yang akan diterapkan.

Berdasarkan hasil implementasi model, secara kuantitatif terbukti bahwa dengan menerapkan model pembelajaran project-work berbasis karakter, mampu mengintegrasikan aspek sikap atau perilaku (soft-skill) dengan aspek kompetensi akademik (hard-skiil) dalam pembelajaran proses pemesinan, sehingga terbentuk karakter peserta didik yang tercermin dari aktivitas atau tingkah laku peserta didik selama proses pembelajaran. Berdasarkan hasil pengamatan selama proses implementasi, khususnya pada tahapan eksplorasi aspek sikap kerja, terlihat bahwa pembelajaran praktik dengan menggunakan model pembelajaran project-work berbasis karakter ini sangat efektif untuk melibatkan peserta didik dalam menggali sekaligus menanamkan kesadaran akan arti pentingnya pembentukan karakter pada proses pemesinan. Pada tahapan ini peserta didik dituntut untuk menyampaikan pendapatnya terkait dengan aspek sikap kerja yang mestinya dimiliki oleh seseorang khususnya dalam melaksanakan pekerjaan yang terkait dengan proses pemesinan. Maksud dari pelaksanaan tahapan ini adalah apabila seseorang telah memiliki kesadaran secara teoritis terkait dengan aspek karakter (yang dilihat dari proses diskusi penyampaian pendapat oleh peserta didik terkait dengan aspek karakter), maka secara logis seseorang tersebut tentunya akan melaksanakan dengan sepenuh hati terhadap berbagai aspek karakter yang terkait dengan praktik pemesinan yang dilaksanakan di kampus. Dengan demikian karakter kerja yang telah diyakini, dihayati dan diamalkan dalam proses pembelajaran tersebut pada akhirnya tentu juga akan dilaksanakan di dunia kerja yang sesungguhnya.

Dari hasil observasi terhadap aktivitas peserta didik selama proses pembelajaran berlangsung, peserta didik yang mampu atau aktif menyampaikan pendapatnya selama proses eksplorasi aspek sikap, ternyata selama proses pembelajaran berlangsung, mereka terbukti dengan tekun melaksanakan aspekaspek sikap terkait dengan karakter kerja dengan baik. Sehingga tahapan eksplorasi aspek karakter ini memang efektif dalam mengintegrasikan aspek karakter dalam proses pembelajaran.

Tahapan lain yang penting untuk diperhatikan dalam penerapan model pembelajaran project-work berbasis karakter adalah diskusi dalam penyusunan rencana kerja (Work Preparaation Sheet). Pada tahapan ini peserta didik dituntut untuk dapat bekerjasama untuk mengatasi masalah dan menghargai pendapat orang lain baik teman dalam kelompoknya maupun kelompok lain. Sehingga dengan melewati tahapan ini mampu membiasakan peserta didik untuk berani berpendapat, menghargai pendapat orang lain, dan kerjasama. Dengan membiasakan 
berdiskusi untuk menyelesaikan suatu masalah, maka peserta didik juga telah tertanam ketrampilan berpikir kritis dan ketrampilan mengatasi masalah. Berpikir kritis dapat mengarah pada pembentukan sifat bijaksana. Berpikir kritis memungkinkan seseorang dapat menganalisis informasi secara cermat dan membuat keputusan yang tepat dalam menghadapi isu-isu yang kontroversial. Oleh sebab itu sangat diharapkan peran pendidik untuk membiasakan peserta didik berpikir kritis, dengan melatihkan kegiatan-kegiatan yang mengandung ciri sebagaimana dikemukakan oleh Kirchenbaum (1995), yaitu meliputi: (1) mencari kejelasan pernyataan atau pertanyaan, (2) mencari alasan, (3) mencoba memperoleh informasi yang benar, (4) menggunakan sumber yang dapat dipercaya, (5) mempertimbangkan keseluruhan situasi, (6) mencari alternatif, (7) bersikap terbuka, (8) mengubah pandangan apabila ada bukti yang dapat dipercaya, (9) mencari ketepatan suatu permasalahan, dan (10) sensitif terhadap perasaan, tingkat pengetahuan, dan tingkat kecanggihan orang lain.

Tahapan lain dalam rangka proses integrasi aspek karakter adalah pada saat proses penilaian benda kerja hasil praktik, dimana sebelum dinilai oleh pengajar maka terlebih dahulu dilakukan self assessment oleh peserta didik. Dalam proses ini, peserta didik wajib melakukan pengukuran secara mandiri terhadap benda kerja mereka masing-masing kemudian diisikan dalam lembar yang sudah disediakan. Tentunya kemudian dilakukan cross check oleh pengajar. Dari kegiatan ini dapat dilihat tingkat kejujuran peserta didik yang tercermin pada hasil self assessment.

Berdasarkan hasil implementasi yang telah dilaksanakan, secara global telah terjadi integrasi aspek karakter dalam proses pembelajaran praktik pemesinan. Hal ini ditunjukkan dari adanya perbedaan aktivitas peserta didik pada saat proses pembelajaran berlangsung. Pada kelas yang menerapkan model pembelajaran project-work berbasis karakter jauh lebih aktif atau lebih baik bila dibandingkan dengan kelas yang tidak menggunakan model pembelajaran tersebut. Berdasarkan hasil penelitian ini juga dapat dilihat bahwa tingkat aktivitas belajar peserta didik berbanding lurus dengan prestasi belajar peserta didik. Hal ini sesuai dengan hasil penelitian Thomas (2012) yang menyatakan bahwa semakin tinggi tingkat aktivitas belajar peserta didik maka akan semakin tinggi pula prestasi belajarnya. Beberapa fakta tersebut menunjukan adanya peningkatan motivasi belajar siswa dalam meraih prestasi akademik pada sekolah-sekolah yang menerapkan pendidikan karakter (Berkowitz, 2010; Rahdiyanta, 2019). Kelas-kelas yang secara komprehensif terlibat dalam pendidikan karakter menunjukkan adanya penurunan drastis pada perilaku negatif siswa yang dapat menghambat keberhasilan akademik. Hal ini juga senada dengan pendapat Joseph Zins (2001), yang menyatakan bahwa faktor-faktor resiko yang menyebabkan kegagalan peserta didik ternyata bukan semata-mata terletak pada kecerdasan otak saja, tetapi juga pada karakter, yaitu rasa percaya diri, kemampuan bekerja sama, kemampuan bergaul, kemampuan berkonsentrasi, rasa empati, dan kemampuan berkomunikasi. Demikian jika dikaitkan dengan pendapat Kirchenbaum (1995), bahwa model pembelajaran project-work berbasis karakter ini jika ditinjau dari segi metodenya merupakan pendekatan pembelajaran yang komprehensif karena memuat aspek-aspek: inkulkasi (inculcation), keteladanan (modeling), dan pengembangan keterampilan (skill building).

Aspek inkulkasi (penanaman nilai) memiliki ciri-ciri sebagai berikut: (1) mengkomunikasikan kepercayaan disertai alasan yang mendasarinya, (2) menghargai pandangan orang lain, (3) menciptakan pengalaman sosial dan emosional mengenai nilai-nilai yang dikehendaki, tidak secara ekstrim, dan (4) membuat aturan, memberikan penghargaan, dan memberikan konsekuensi disertai alasan. Aspek keteladanan nilai dapat menumbuhkan keterampilan asertif dan keterampilan menyimak pada peserta didik. 
Keterampilan ini sangat diperlukan untuk menjalin hubungan antar pribadi dan antar kelompok (Rahdiyanta, 2014). Keterampilan asertif adalah keterampilan mengemukakan pendapat secara terbuka, dengan cara-cara yang tidak melukai perasaan orang lain. Sedangkan keterampilan menyimak adalah keterampilan mendengarkan dengan penuh pemahaman dan secara kritis. Kedua ketrampilan ini oleh Zuchdi (2009) digambarkan sebagai yin dan yang, yang keduanya harus dikembangkan secara seimbang karena merupakan komponen vital dalam berkomunikasi. Aspek fasilitasi nilai merupakan bantuan atau bimbingan dari pendidik kepada peserta didik untuk mengatasi masalah yang dihadapinya. Kegiatan fasilitasi nilai terbukti membawa dampak positif pada perkembangan kepribadian peserta didik, yang antara lain meliputi: (1) meningkatkan hubungan pendidik dan subjek didik, (2) menolong subjek didik memperjelas pemahaman, (3) mendorong subjek didik berpikir lebih jauh tentang nilai yang dipelajari, menemukan wawasan sendiri, dan pada akhirnya menyadari kebaikan hal-hal yang disampaikan oleh pendidik, (4) pendidik lebih dapat memahami pikiran dan perasaan subjek didik, dan (5) memotivasi subjek didik menghubungkan persoalan nilai dengan kehidupan, kepercayaan, dan perasaan mereka sendiri.

\section{SIMPULAN}

Kesimpulan dari penelitian ini adalah terdapat perbedaan perilaku atau aktivitas belajar antara mahasiswa yang diajar dengan menerapkan model pembelajaran project-work berbasis karakter (kelas eksperimen), dibandingkan dengan mahasiswa yang tidak diajar dengan menggunakan model pembelajaran project-work berbasis karakter (kelas control) pada mata kuliah praktik pemesinan $(t=7,31 ; p=0,000)$. Dalam hal nilai-nilai karakter yang telah terlaksana dengan konsisten dan membudaya pada diri mahasiswa pada kelas eksperimen sebesar 90\% dan pada kelas kontrol sebesar 64\%. Selain itu, terdapat juga perbedaan prestasi belajar antara mahasiswa yang diajar dengan menerapkan model pembelajaran project-work berbasis karakter (kelas eksperimen), dibandingkan dengan mahasiswa yang tidak diajar dengan menggunakan model pembelajaran projectwork berbasis karakter (kelas kontrol) pada mata kuliah praktik pemesinan $(\mathrm{t}=9,47 ; \mathrm{p}=$ $0,000)$. Rata-rata prestasi belajar mahasiswa yang diajar dengan menerapkan model pembelajaran project-work berbasis karakter lebih tinggi dibandingkan dengan prestasi belajar mahasiswa yang diajar tidak menggunakan model pembelajaran projectwork berbasis karakter pada mata kuliah praktik pemesinan $\left(X_{\text {eksperimen }}=81,35>X_{\text {konrol }}=66,29\right)$.

\section{DAFTAR RUJUKAN}

Alamaki, A. (2014). Current trends in technology education in Findland. The Journal of Technology Studies, 26(1), 110-119.

Arends, R. I. (2010). Learning to teach. Singapore: McGraw-Hill book Company.

Berkowitz, M. W. (2010). The Education of Complete Moral Person. Dalam buletin, Character Educator, yang diterbitkan oleh Character Education Partnership.

Bern, R.G., \& Erikson, P.M. (2010). Contextual teaching and learning. Preparing students for the new economy. Ohio: Bowling Green State University.

Borg, W.R., \& Gall, M. D. (1998). Educational Research, an introduction. New York: Longman.

Calhoun, C.C. and Finch, C.R. (1976). Vocational educational: Concepts and operation, Belmont: Wadsworth Publishing Company. 
Depdiknas. (2003). Konsep Pendidikan Berorienatsi Kecakapan Hidup (Life skill) Melalui Pendekatan Pendidikan Berbasis Kelas (Broad Base Education$B B E)$. Jakarta: Depdiknas.

Finch, C.R. and Crunkilton, J.R. (1979). Curriculum development in vocational education, Boston: Allyn and Bacon Inc.

Fortus, D., et al. (2015). Incorporating modeling practices into middle school project-based science. Laporan Penelitian. Weizmann Institute of Science.

Kemdiknas. (2010). Buku Induk Pembangunan Karakter. Jakarta: Kem-diknas.

Kemdiknas. (2010). Panduan Pelaksanaan Pendidikan Karakter. Jakarta: Kemdiknas.

Rahdiyanta, D. (2019). Penerapan Model Pembelajaran Praktik Berbasis Collaborative Skill sebagai Upaya Peningkatan Mutu Pendidikan Tinggi Vokasi. Jurnal Dinamika Vokasional
Teknik Mesin, 1(1) 2016, 1-9.

Rahdiyanta, D., Nurhadiyanto, D., \& Munadi, S. (2019). The Effects of Situational Factors in the Implementation of WorkBased Learning Model on Vocational Education in Indonesia. International Journal of Instruction, 12(3), 307-324.

Thomas, J.W. (2012). A review of research on project-based learning. California: The Autodesk Foundation.

Wardiman Joyonegoro, (1998). Pengembangan sumberdaya manusia melalui SMK. Jakarta: PT. Jayakarta Agung Offset.

Zins, Joseph E., et.al. (2001). Building Academic Success on Social and Emotional Learning: What Does the Research Say? New York: Teachers College Press.

Zuchdi, Darmiyati, (2009). Pendidikan karakter grand design dan nilai-nilai target. Yogyakarta: UNY Press.

. UU No 20 Tahun 2003

Tentang Sistem Pendidikan Nasional. 